Surgery for

Congenital Heart

Disease

\title{
Single-ventricle palliation for high-risk neonates: The emergence of an alternative hybrid stage I strategy
}

Emile A. Bacha, MD, ${ }^{\text {a }}$ Suanne Daves, MD, ${ }^{\mathrm{b}}$ Joel Hardin, MD, ${ }^{\mathrm{c}}$ Ra-id Abdulla, MD, ${ }^{\mathrm{c}}$ Jennifer Anderson, MD, ${ }^{\mathrm{c}}$ Madelyn Kahana, MD, ${ }^{b}$ Peter Koenig, MD, ${ }^{c}$ Bassem N. Mora, MD, ${ }^{a}$ Mehmet Gulecyuz, MD, ${ }^{c}$ Joanne P. Starr, MD, Ernerio Alboliras, MD, ${ }^{c}$ Satinder Sandhu, MD, ${ }^{c}$ and Ziyad M. Hijazi, MD ${ }^{c}$

Earn CME credits at http://cme.ctsnetjournals.org

丹 Supplemental material is available online.
From the Departments of Congenital and Pediatric Cardiac Surgery, ${ }^{\text {a }}$ Anesthesia and Critical Care, ${ }^{\mathrm{b}}$ and Pediatric Cardiology, ${ }^{\mathrm{c}}$ The University of Chicago Children's Hospital, Chicago, Ill.

Read at the Eighty-fifth Annual Meeting of The American Association for Thoracic Surgery, San Francisco, Calif, April 10-13, 2005.

Received for publication April 8, 2005; revisions received July 14, 2005; accepted for publication July 19, 2005.

Address for reprints: Emile A. Bacha, MD, Cardiac Surgery, Children's Hospital Boston, 300 Longwood Ave, Bader 273, Boston, MA 02115 (E-mail: emile.bacha@ cardio.chboston.org).

J Thorac Cardiovasc Surg 2006;131:163-71

$0022-5223 / \$ 32.00$

Copyright () 2006 by The American Association for Thoracic Surgery

doi:10.1016/j.jtcvs.2005.07.053
Background: Survival after stage I palliation for hypoplastic left heart syndrome or related anomalies remains poor in high-risk neonates. We hypothesized that a less invasive hybrid approach would be beneficial in this patient population.

Methods: The hybrid stage I procedure was performed in the catheterization laboratory. Via a median sternotomy, both branch pulmonary arteries were banded, and a ductal stent was delivered via a main pulmonary artery puncture and positioned under fluoroscopic guidance.

Results: Between October 2003 and June 2005, 14 high-risk neonates underwent a hybrid stage I procedure. Eleven of 14 had hypoplastic left heart syndrome. Two also underwent peratrial atrial septal stenting, and 5 required percutaneous atrial stenting later. Two neonates with an intact or highly restrictive atrial septum had emergency percutaneous atrial stent placement. Hospital survival was $11(78.5 \%)$ of 14. One patient required extracorporeal membrane oxygenation support for intraoperative cardiac arrest. He underwent cardiac transplantation but died later of sepsis. One patient died of ductal stent embolization, and a third died of progressive cardiac dysfunction. The first 4 patients required pulmonary artery band revisions. There were none after we modified our technique and added branch pulmonary artery angiograms. There were 2 interstage deaths from atrial stent occlusion and from preductal retrograde coarctation. Eight patients underwent stage II procedures, consisting of aortic arch reconstruction, atrial septectomy, and cavopulmonary shunt. Two patients died after stage II. One patient is awaiting stage II.

Conclusions: The hybrid stage I palliation is a valid option in high-risk neonates. As experience is accrued, it may become the preferred alternative. However, in aortic atresia, the development of preductal retrograde coarctation is a significant problem.

$\mathrm{D}$ espite undeniable recent improvements in survival, ${ }^{1-5}$ the Norwood stage I operation for hypoplastic left heart syndrome (HLHS) and related anomalies remains a high-risk endeavor. Even a perfectly executed operation requires prolonged cardiopulmonary bypass (CPB) with occasional deep hypothermic circulatory arrest, multiple blood transfusions, and delayed sternal closure. Prolonged neonatal CPB, hospitalization, or both, especially in the setting of hypoxemia and low diastolic pressures, has been linked to poor neurologic devel- 


\section{Abbreviations and Acronyms \\ $\mathrm{CPB}=$ cardiopulmonary bypass \\ HLHS = hypoplastic left heart syndrome \\ PA = pulmonary artery \\ PTFE = polytetrafluoroethylene}

opment. ${ }^{6-8}$ Risk factors include presentation with shock, birth weight less than $2.5 \mathrm{~kg}$, prematurity ( $<34$ weeks' gestational age), less than a 2-mm ascending aorta, poor ventricular function, tricuspid regurgitation, intact or restrictive atrial septum, additional cardiac anomalies, or serious noncardiac genetic malformations. ${ }^{1,3,5,9,10}$ Although the significance of some of the listed risk factors can be argued with modern management, high-risk neonates undergoing a stage I Norwood operation still face a mortality of $20 \%$ to $50 \%$. $^{3,5}$ Thus, a less invasive method of stage I palliation that effectively palliates symptoms while delaying the surgical reconstruction until some of the risk factors are sorted out should be advantageous.

Branch pulmonary artery (PA) banding is one of the earliest methods of stabilization in $\mathrm{HLHS}^{11}$ and remains popular today in dire situations ${ }^{12,13}$ or as pretransplantation stabilization. ${ }^{14}$ Encouraged by the initial success of ductal stenting, some groups ${ }^{15,16}$ began using percutaneous ductal stenting followed by surgical band placement for initial palliation of HLHS. The approach was then modified by performing ductal stenting via a sternotomy and PA puncture, thus avoiding the issues of percutaneous access, arrhythmias, and valvular regurgitation associated with percutaneous procedures. ${ }^{17}$ Ultimately, this strategy could potentially lead to a percutaneous Fontan completion, ${ }^{18}$ with 1 major on-pump reconstruction sandwiched between 2 interventional procedures. This article reviews our initial experience with this strategy and highlights potential advantages and shortcomings.

\section{Materials and Methods}

The study was performed at The University of Chicago Comer Children's Hospital and was approved by the institutional review board. Informed consent was obtained, and all procedures were conducted in accordance with institutional guidelines. A prospective database was maintained, and recently, all patient records were reviewed. The most recent follow-up data were obtained from the last outpatient visit. All genetic syndromes were diagnosed by a pediatric geneticist.

The procedure is performed in the catheterization laboratory, which is prepared by having the surgical nursing team set up instruments as if in the actual operating room. A transesophageal echocardiography probe is placed if the atrial septum is to be approached. Under usual monitoring, the chest, abdomen, and groin are prepared and draped. A median sternotomy is performed. The chest retractor is placed in such a way as to be able to be removed when fluoroscopy is performed. Rings $1.5 \mathrm{~mm}$ wide are

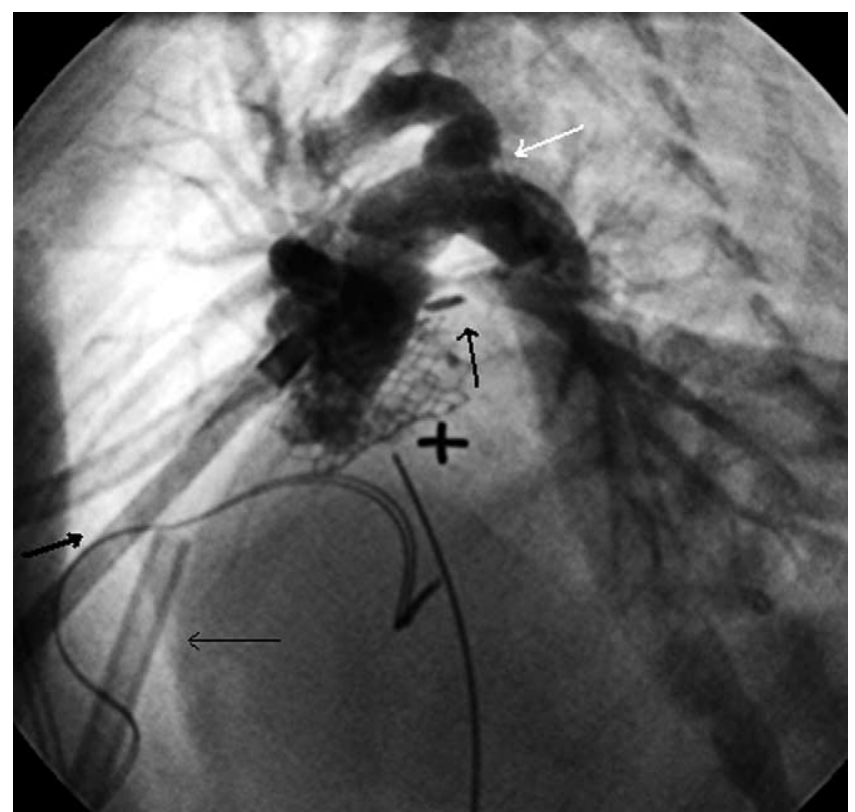

Figure 1. Initial angiogram obtained after branch PA banding (patient 13). The left pulmonary artery band is seen (thick black arrow). The isthmus is widely patent in this case (white arrow). An atrial stent is seen (placed urgently for restrictive atrial septum). The right atrial appendage also contains a purse-string suture with a tourniquet (thin black arrow) through which an atrial line was passed. The main pulmonary artery sheath is depicted with a thick black arrow.

cut off a standard 3.5-mm polytetrafluoroentylene (PTFE) tube graft (Gore-Tex tube graft; W. L. Gore \& Associates, Inc, Flagstaff, Ariz) and cut open. A 5-0 polypropylene mattress suture is placed through one end of the cut ring. The right PA is encircled to the right of the ascending aorta, and the PTFE band is pulled through by using the arms of the 5-0 suture. The suture is then passed through the other end of the band and tied. A clip is placed over the sutured portion, and further clips can be used to tighten further, if necessary. The left PA is similarly banded at its origin. It is important to avoid dissecting the branch PAs more than necessary so the surrounding tissues can be used as protection against band migration. Because of 1 instance of distal band migration (patient 12), we now use extra sutures fixing the band to surrounding tissues to prevent this significant problem.

Next, a 5-0 polypropylene purse-string suture is placed at the sinotubular junction of the main PA. Heparin $50 \mathrm{IU} / \mathrm{kg}$ is given. The main PA is punctured with a 21-gauge needle (Cook Inc, Bloomington, Ind), and a 0.018 -inch short guidewire is passed into the descending aorta via the ductus. A short $6 \mathrm{~F}$ sheath is then advanced over the guidewire, positioned with the tip inside the vessel by 2 to $3 \mathrm{~mm}$ only, and secured as if an aortic cannula would be secured. An angiogram is performed by using the sheath in the main PA in a $45^{\circ}$ left anterior oblique angulation to profile the aortic arch and ascending aorta, measure the ductal diameter, and assess the position and appropriateness of the bands (Figure 1). The proper size of self-expandable stent (usually 7 or $8 \times 20 \mathrm{~mm}$ ) 


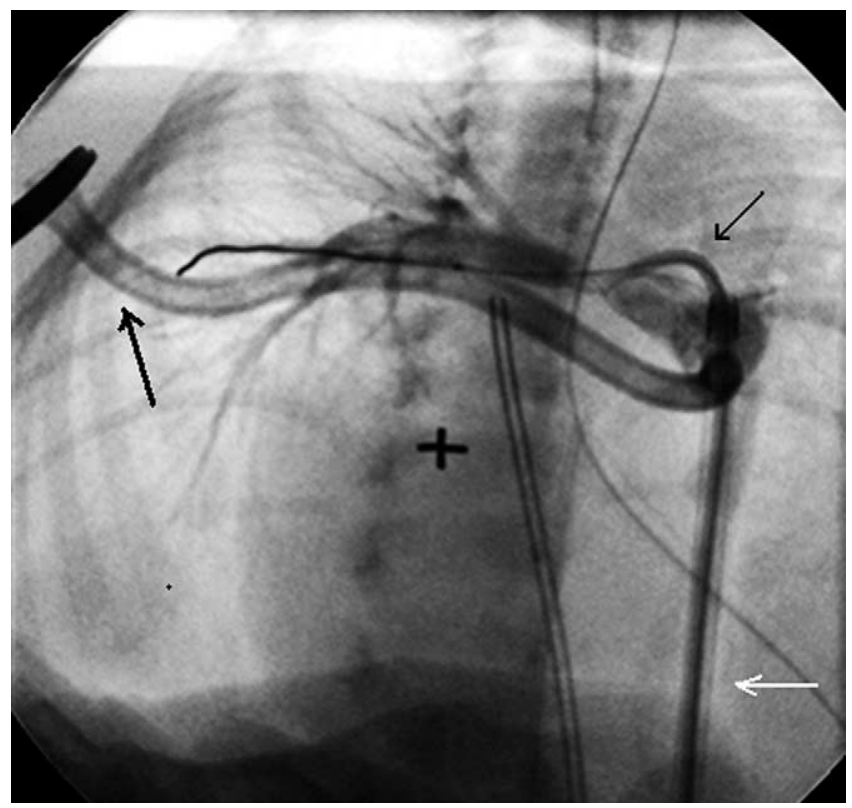

Figure 2. A Judkins Right catheter (thin black arrow) is passed through the main PA sheath (white arrow) and positioned over a flexible wire in the right PA for selective angiography (patient 12). The band is too loose. The tourniquet holding the sheath is shown by a thick black arrow.

is then advanced over the guidewire. The stent is placed so that the distal end of it is just protruding into the descending aorta and the proximal part is just above the branch PA openings. We have been using either the Precise (Cordis, Johnson \& Johnson, Warren, NJ) or Protégé (ev3 Inc, Plymouth, Minn) stents. Once the stent is deployed, a repeat angiogram is performed to assess the position of the stent, the PA bands, and the aortic arch. If the stent is not covering the entire ductus, another stent is deployed to overlap the first stent ( 1 case in our experience). If the PA bands are deemed to be too tight or too loose, they can be adjusted accordingly. In addition to using the arterial saturation or blood pressure as a guide for band diameter, we aim for a diameter of the banded portion of the PA to be approximately $30 \%$ to $40 \%$ of the diameter of the proximal PA. If the bands cannot be profiled adequately, we have inserted a Judkins Right catheter into the sheath and performed selective branch PA angiograms (Figure 2). If the atrial septum is restrictive, then the atrial communication can be enlarged by using a self-expandable stent placed via a peratrial approach under transesophageal echocardiography guidance. An intracardiac common atrial monitoring line is always placed before chest closure.

\section{Results}

Between November 2003 and June 2005, we performed 14 hybrid stage I procedures, consisting of single-stage ductal stenting and bilateral branch PA banding (Table 1). Eleven patients (78.5\%) had HLHS. The median weight was $2.8 \mathrm{~kg}$ (range, 2.2-3.3 kg), and the median age was 5.7 days (range, 1-17 days). Preoperative risk factors were present in all patients and included aortic atresia in 8 , severe noncardiac genetic anomaly and weight less than $2.5 \mathrm{~kg}$ in 4 , poor ventricular function in 3 , intact or highly restrictive atrial septum and additional cardiac defect in 2, and prematurity ( $<34$ weeks' gestational age), intracerebral bleed, presentation in shock, left ventricular coronary fistulas, partial left diaphragmatic hernia, and necrotizing enterocolitis in 1 each. All patients were intubated before surgery. All patients but one had their chests closed primarily. Two required an intraoperative increase or initiation of inotropic support. Operation ("skin-skin") time was $100 \pm 37$ minutes.

Hospital survival after hybrid stage I procedures was 11 (78.5\%) of 14 patients. There were 3 in-hospital deaths: 1 patient (no. 2) had a cardiac arrest during passage of the wire into the descending aorta. He required emergency extracorporeal membrane oxygenation support and subsequently required heart transplantation. He died of sepsis at 8 weeks of age. We speculate that a coronary clot caused the arrest, although inspection of the explanted heart failed to conclusively settle the question. Another death occurred on the day before hospital discharge because of stent dislodgment into the descending aorta with subsequent ductal constriction and death (patient 9). The third in-hospital death occurred in a severely dysmorphic patient (no. 12) with severe preoperative ventricular dysfunction and tricuspid regurgitation, who, on the basis of her genetic dysmorphism, was deemed not to be a candidate for extracorporeal membrane oxygenation. The procedure was uneventful (Figure 3), but her cardiac output continued to deteriorate, and she had a cardiac arrest 6 hours after the operation.

There were 2 interstage fatalities: 1 patient (no. 4) died immediately before his scheduled stage II procedure of atrial stent migration and subsequent atrial septal restriction (Figures E1 and E2). Another patient (no. 10) with HLHS and an intact atrial septum was discharged from the hospital 19 days after successful percutaneous atrial stenting followed by a hybrid stage I procedure. He died suddenly 8 days after discharge. Autopsy showed a 2-mm opening into the transverse arch with ductal tissue surrounding that opening.

Survival to stage II was $8(61 \%)$ of 13 . Eight patients underwent a stage II reconstruction consisting of stent removal, aortic arch reconstruction, and cavopulmonary shunt in 7 and conversion to biventricular repair in 1. One patient (no. 7) had a 3-mm opening into his arch diagnosed during angiography (Figure 4). Six patients survived. One died from superior vena cava thrombosis related to heparininduced thrombocytopenia, and 1 died from low cardiac output. One other patient later died at home at age 8 months from a sudden infection likely related to severe T-cell malfunction related to DiGeorge syndrome. One patient is currently awaiting a stage II operation. 
TABLE 1. Clinical experience with 14 consecutive hybrid stage I procedures (November 2003 to June 2005)

\begin{tabular}{|c|c|c|c|c|c|}
\hline Patient no. & Diagnosis & $\begin{array}{l}\text { Age (d)/weight } \\
(\mathrm{kg})\end{array}$ & Risk factor(s) & Atrial septum & $\begin{array}{l}\text { Intraoperative } \\
\text { complications }\end{array}$ \\
\hline 1 & HLHS (AS, MS) & $5 / 2.9$ & $\begin{array}{l}\text { Very poor ventricular function, } \\
\text { moderate TR }\end{array}$ & Nonrestrictive & $\begin{array}{l}2 \text { ductal stents placed to } \\
\text { cover entire duct }\end{array}$ \\
\hline 2 & HLHS (AA, MS) & $1 / 3.2$ & $A A$, severe $\mathrm{LVH}$ & Peratrial stent & Cardiac arrest \\
\hline 3 & $\begin{array}{l}\text { IAA(C), CAVC, } \\
\text { BSVC }\end{array}$ & $9 / 2.6$ & CHARGE syndrome & Nonrestrictive & No \\
\hline 4 & $\begin{array}{l}\text { HLHS (AA,MA), } \\
\text { L-TGA }\end{array}$ & $17 / 3.3$ & $\begin{array}{l}\text { AA, NEC (intestinal } \\
\text { pneumatosis) }\end{array}$ & Nonrestrictive & Unable to band LPA \\
\hline 5 & HLHS (AA, MA) & $3 / 3.1$ & $\begin{array}{l}\text { AA, congenital } \\
\text { tracheomalacia }\end{array}$ & Peratrial stent & Arrhythmias \\
\hline 6 & $\begin{array}{l}\text { IAA }(C), A S \\
\text { subAS, VSD }\end{array}$ & $4 / 2.7$ & $\begin{array}{l}\text { Confirmed T-cell dysfunction } \\
\text { (DiGeorge), congenital } \\
\text { partial left diaphragmatic } \\
\text { hernia }\end{array}$ & Nonrestrictive & No \\
\hline 7 & HLHS (AA, MA) & $6 / 2.2$ & $\begin{array}{c}\text { AA, weight, } 32 \text { wk gestational } \\
\text { age, LV-coronary fistulas }\end{array}$ & Nonrestrictive & No \\
\hline 8 & HLHS (AA, MA) & $1 / 3.2$ & $A A$ & Nonrestrictive & No \\
\hline 9 & $\mathrm{IAA}(\mathrm{B}) / \mathrm{CAVC}$ & $5 / 2.4$ & Weight & Nonrestrictive & No \\
\hline 10 & HLHS (AA, MA) & $7 / 3$ & AA, intact atrial septum & Percut. RFA + atrial stent & No \\
\hline 11 & $\begin{array}{l}\text { HLHS (AA, } \\
\text { MS), BSCV }\end{array}$ & $5 / 2.5$ & $\begin{array}{l}\text { Cerebral bleed, AA, shock, } \\
\text { CHARGE syndrome }\end{array}$ & Nonrestrictive & No \\
\hline 12 & $\begin{array}{l}\text { HLHS (AA, } \\
\text { MA), PAPVR, } \\
\text { dextrocardia }\end{array}$ & $7 / 2.7$ & $\begin{array}{l}\text { Severe ventricular } \\
\text { dysfunction, moderate TR, } \\
\text { nondescript genetic } \\
\text { syndrome }\end{array}$ & Nonrestrictive & No \\
\hline 13 & HLHS (AA, MS) & $4 / 3.2$ & Highly restrictive atrial septum & Percut. atrial stent DOL 1 & No \\
\hline 14 & HLHS (AA, MS) & $3 / 2.4$ & $\begin{array}{l}\text { AA, weight, intestinal } \\
\text { malrotation }\end{array}$ & Mildly restrictive & No \\
\hline
\end{tabular}

The atrial septum was initially deemed nonrestrictive in 10 of 14 patients. Two patients underwent peratrial deployment of an atrial septal stent via a direct puncture of the right atrial free wall during hybrid stage I. Another 2 patients had an intact or near-intact atrial septum and underwent emergency percutaneous placement of an atrial stent right after birth. Four of the 10 who were initially deemed nonrestrictive required percutaneous atrial stenting at $1,1.5,2$, and 3 months after surgery. Two patients had atrial stent migration; 1 died at home, and the other required open surgical septostomy.

One patient required repeat percutaneous stenting because of distal migration of the ductal stent. Bands had to be tightened via resternotomy in the first 4 patients. Two patients required left PA stenting shortly after stage II.

Our current protocol is to proceed with the hybrid stage I procedure early after birth. Postoperative management is routine. We perform echocardiograms at least weekly, even after discharge. At 6 weeks, consideration is given to a cardiac catheterization to check the position of the stent(s) and bands (Figure E3). If the atrial septum is restrictive, it is stented or dilated at that time. The stage II procedure is performed at 12 to 24 weeks of age.

\section{Discussion}

The 3 tenets of stage I palliation for HLHS are the establishment of an unobstructed systemic outflow, a nonrestrictive atrial septal defect, and a controlled source of pulmonary blood flow. Coronary blood flow also needs to be reliable. If the hybrid stage I procedure is to be successful, it has to ultimately satisfy all of these criteria.

Despite a difficult learning curve, this pilot series of 14 consecutive hybrid stage I palliation procedures demonstrates that acceptable results can be achieved in a very- 


\begin{tabular}{|c|c|c|c|c|c|}
\hline Postop course & $\begin{array}{c}\text { Interstage } \\
\text { complications }\end{array}$ & $\begin{array}{c}\text { Age }(\mathrm{mo}) / \\
\text { weight }(\mathrm{kg}) \\
\text { at stage II }\end{array}$ & $\begin{array}{c}\text { Intraop } \\
\text { complications }\end{array}$ & Postop course & $\begin{array}{c}\text { Status/age } \\
\text { at } F / U\end{array}$ \\
\hline Benign & $\begin{array}{l}\text { LPA rebanding and percut } \\
\text { atrial stent } 3 \text { mo postop }\end{array}$ & $3.5 / 4.2$ & No & $\begin{array}{l}\text { Prolonged inotropes } \\
\text { for poor ventr fct }\end{array}$ & Well/20 mo \\
\hline ECMO-heart Tx & Died of sepsis age $8 w k$ & $\mathrm{~N} / \mathrm{A}$ & N/A & $\mathrm{N} / \mathrm{A}$ & Dead \\
\hline Benign & $\begin{array}{l}\text { Poor feeding (cleft lip/ } \\
\text { palate) }\end{array}$ & $5 / 4.3$ & Bleeding & Benign & Well/19 mo \\
\hline $\begin{array}{l}\text { LPA band via left } \\
\text { thoracotomy; percut. } \\
\text { atrial stent } 5 \text { wk } \\
\text { postop }\end{array}$ & $\begin{array}{l}\text { Died at } 5 \text { mo of subacute } \\
\text { occlusion atrial stent } \\
\text { (autopsy) }\end{array}$ & $\mathrm{N} / \mathrm{A}$ & N/A & $\mathrm{N} / \mathrm{A}$ & Dead \\
\hline $\begin{array}{l}\text { Ductal stent migration, } \\
\text { percut } 2 \mathrm{~d} \text { ductal } \\
\text { stent, tracheostomy }\end{array}$ & $\begin{array}{l}\text { Atrial septect. for atrial } \\
\text { stent stenosis and LPA } \\
\text { rebanding }\end{array}$ & $4 / 4.3$ & $\begin{array}{l}\text { Difficult distal } \\
\text { aortic stent } \\
\text { removal }\end{array}$ & $\begin{array}{l}\text { Died from HITT } \\
\text { (thrombosed CPS) }\end{array}$ & Dead \\
\hline Benign & No & $\begin{array}{l}\text { 4/4.2 (Yasui } \\
\quad \text { biventricular } \\
\text { repair) }\end{array}$ & $\begin{array}{l}\text { ECMO } \times 4 \mathrm{~d} \text { for } \\
\text { malignant } \\
\text { arrhythmias }\end{array}$ & D/C POD 40 & $\begin{array}{l}\text { Sudden death at } \\
\text { home } / 8 \mathrm{mo}\end{array}$ \\
\hline Benign & $\begin{array}{l}\text { Preductal } \mathrm{CoA} \text { at pre- } \\
\text { stage II cath }\end{array}$ & $3 / 4.5$ & LPA reconstruction & $\begin{array}{l}\text { LPA stent POD } 42, \\
\text { thrombosed LPA } \\
\text { POD } 72\end{array}$ & Well/13 mo \\
\hline Benign & $\begin{array}{l}\text { Percutaneous atrial stent } \\
\text { placed } 6 \text { wk postop }\end{array}$ & $3 / 5.5$ & No & LPA stent POD 55 & Well/13 mo \\
\hline $\begin{array}{l}\text { Died POD } 18 \text { (ductal } \\
\text { stent embolization) }\end{array}$ & $\mathrm{N} / \mathrm{A}$ & $\mathrm{N} / \mathrm{A}$ & $\mathrm{N} / \mathrm{A}$ & $\mathrm{N} / \mathrm{A}$ & Dead \\
\hline Benign & $\begin{array}{l}\text { Sudden death at outside } \\
\text { hospital }\end{array}$ & $\mathrm{N} / \mathrm{A}$ & N/A & $\mathrm{N} / \mathrm{A}$ & Dead \\
\hline Benign & No & $4 / 5.0$ & LPA reconstruction & ECMO & Dead \\
\hline $\begin{array}{l}\text { Cardiac arrest } 6 \mathrm{~h} \\
\text { postop (not ECMO } \\
\text { cand.) }\end{array}$ & $\mathrm{N} / \mathrm{A}$ & $\mathrm{N} / \mathrm{A}$ & $\mathrm{N} / \mathrm{A}$ & $\mathrm{N} / \mathrm{A}$ & Dead \\
\hline Failed extubation & No & $3 / 4.1$ & No & Moderate TR & Well/5 mo \\
\hline $\begin{array}{l}\text { Ladd procedure for } \\
\text { malrotation on POD } 4\end{array}$ & $\begin{array}{l}\text { Percutaneous atrial } \\
\text { septostomy }\end{array}$ & $\mathrm{N} / \mathrm{A}$ & $\mathrm{N} / \mathrm{A}$ & $\mathrm{N} / \mathrm{A}$ & $\begin{array}{l}\text { Well, } 4 \text { wk, } \\
\text { awaiting stage II }\end{array}$ \\
\hline
\end{tabular}

$A A$, Aortic atresia; $A S$, aortic stenosis; $B S V C$, bilateral superior venae cavae; cand, candidate; cath, catheterization; $C A V C$, complete atrioventricular canal; CHARGE syndrome, coloboma, heart defects, atresia of the choanae, retardation of growth and development, genital and urinary abnormalities, and ear abnormalities and/or hearing loss; $C O A$, coarctation of the aorta; $C P S$, cavopulmonary shunt; $D / C$, discharged; $D O L$, day of life; $E C M O$, extracorporeal membrane oxygenation; fct, function; $F / U$, follow-up; $I A A(C)$, interruption of the aortic arch (complete); intraop, during surgery; postop, after surgery; $H L H S$, hypoplastic left heart syndrome; HITT, heparin-induced thrombocytopenia and thrombosis; $L P A$, left pulmonary artery; $L V$, left ventricle; $L V H$, left ventricular hypertrophy; $L-T G A$, levo-transposition of the great arteries; $M A$, mitral atresia; $M S$, mitral stenosis; $N / A$, not applicable; $N E C$, necrotizing enterocolitis; $P A P V R$, partial anomalous pulmonary venous return; precut 2-d, percutaneous 2-dimensional; POD, postoperative day (always refers to last operation performed); RFA, radiofrequency ablation of atrial septum; septect, septectomy; $T R$, tricuspid regurgitation; $T X$, transplantation; ventr, ventricular; VSD, ventricular septal defect.

high-risk group. No patient was excluded from the study, and, thus, this report encompasses all the technical or decisionmaking errors that were due to our unfamiliarity with this procedure. With more experience, time, and new technology, results should improve.

Obstruction of pulmonary venous return and the presence of a significant noncardiac malformation or genetic syndrome are independent risk factors demonstrated in multivariable analy- ses. ${ }^{3,5,10,19}$ Mortalities in the range of 50\% are reported. ${ }^{3,5,19}$ Four patients had genetic syndromes, and 2 had severe obstruction of pulmonary venous return. Out of this very-highrisk group of 6 patients ( 2 also had additional cardiac defects), 5 survived to discharge after hybrid stage I procedures. Although this is a very small group of patients, therein may lie the most obvious benefit of this procedure. This has also been the finding of other groups involved in this field. ${ }^{17,20}$ 


\section{Pros and Cons of the Hybrid Stage I}

Pros. The main advantages include avoidance of neonatal $\mathrm{CPB}$, the possibility of achieving complete palliation with 2 pump runs instead of 3 , and the avoidance of early neonatal trauma due to prolonged hospitalization. Longterm neurologic development and IQ after the Norwood stage I procedure have been historically unsatisfactory, specifically with the combination of hypoxemia and low diastolic pressure that can be a typical feature of postoperative care. ${ }^{7}$ Periventricular leukomalacia has been seen in more than $50 \%$ of neonates after complex repairs, but it is rare in infants. $^{7}$

The stage II reconstruction is a very challenging redo operation, involving stent removal, arch reconstruction, and cavopulmonary shunting. However, the patient recovers with circulation in series and not in parallel, as occurs after the Norwood stage I. Early palliation with circulation in parallel, as in the Norwood operation, requires that ventricular output must be maintained at a level that is 2 to 3 times normal. ${ }^{21}$ Right ventricular function has been shown to be better after cavopulmonary shunt operations than after volumeloading procedures. ${ }^{22}$ Finally, there is evidence that myocardial damage after heart surgery is greater in neonates as opposed to infants. ${ }^{23,24}$

Cons. Disadvantages of this procedure include recent data showing decreased preoperative cerebral blood flow in neonates with complex congenital heart disease. ${ }^{25}$ In aortic

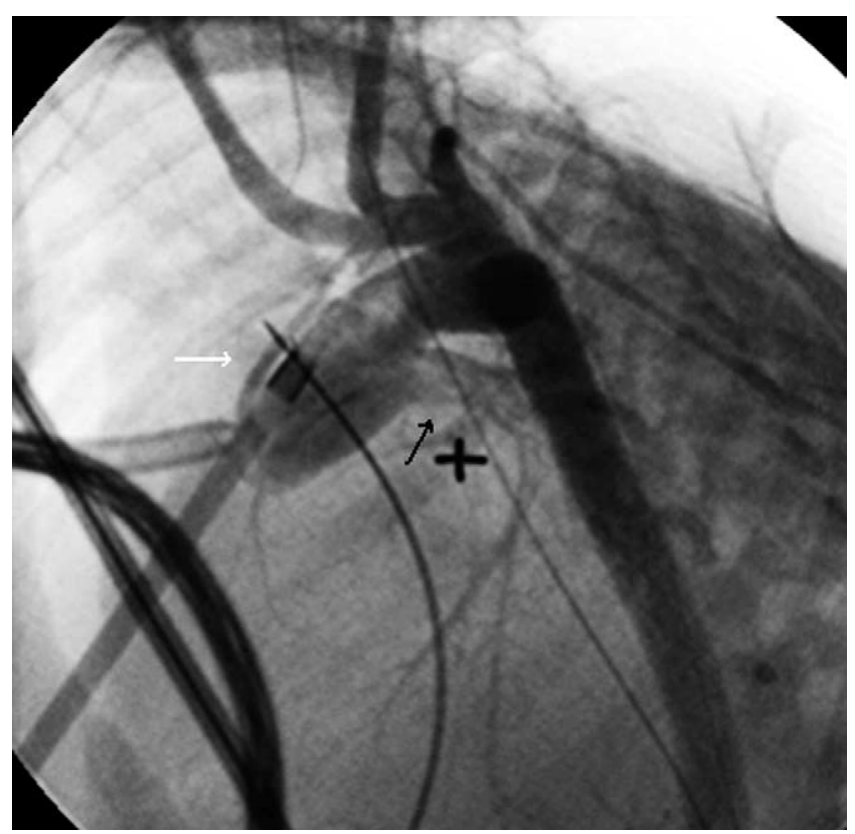

Figure 3. An extremely diminutive ascending aorta is shown on the initial angiogram (white arrow). This patient (patient 12) with multiple genetic anomalies presented with severe ventricular dysfunction, which progressed after a hybrid stage I procedure. Coronary flow may have been impaired.

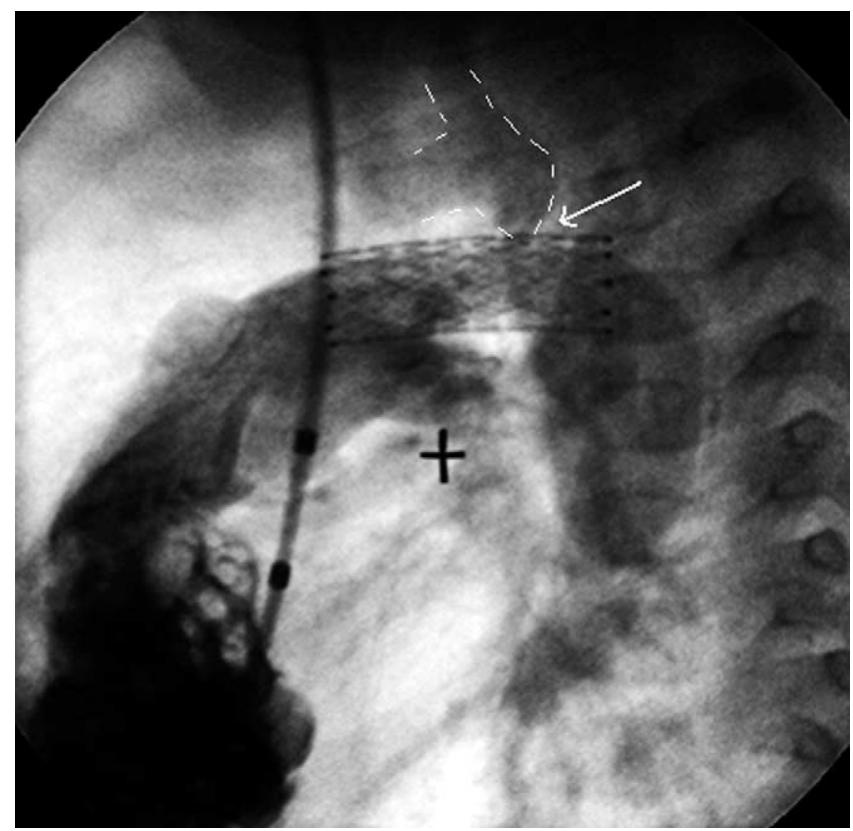

Figure 4. Pre-stage II angiogram at 3 months shows preductal coarctation. This patient (patient 4) was taken to the operating room the next day.

atresia, the possibility of coronary malperfusion or cerebral malperfusion is real if the isthmus or a portion of the transverse arch becomes stenotic. The ductal stent by necessity covers the isthmic opening into the transverse arch because it has to cover the entire duct to prevent ductal constriction (Figure 5). In aortic atresia patients, we now specifically image the entire aortic arch and ascending aorta during the initial angiogram (Figure 1) to exclude any significant stenoses that, if present, would preclude us from proceeding with hybrid stage I palliation. However, that may not be the solution to this problem, because histopathologic studies of HLHS specimens have documented that ductal tissue often extends in the preductal position, especially in aortic atresia. ${ }^{26,27}$ Therefore, at this time, there is no way to reliably exclude that possibility, because even a nonstenotic isthmus may become stenotic once prostaglandins are discontinued. This may be the Achilles heel of the hybrid stage I procedure. Further morphologic research is needed to describe the frequency of preductal coarctation in HLHS with aortic atresia, as is improved and more accurate recognition of this problem before surgery. Technically, ductal stenting per se was uncomplicated. Because of the 2 instances of distal stent migration, we now routinely measure the ductal width on initial arch angiogram and oversize the stent by $1 \mathrm{~mm}$. Another option would be to use balloonexpandable stents, with which we do not have any experience in this setting. 


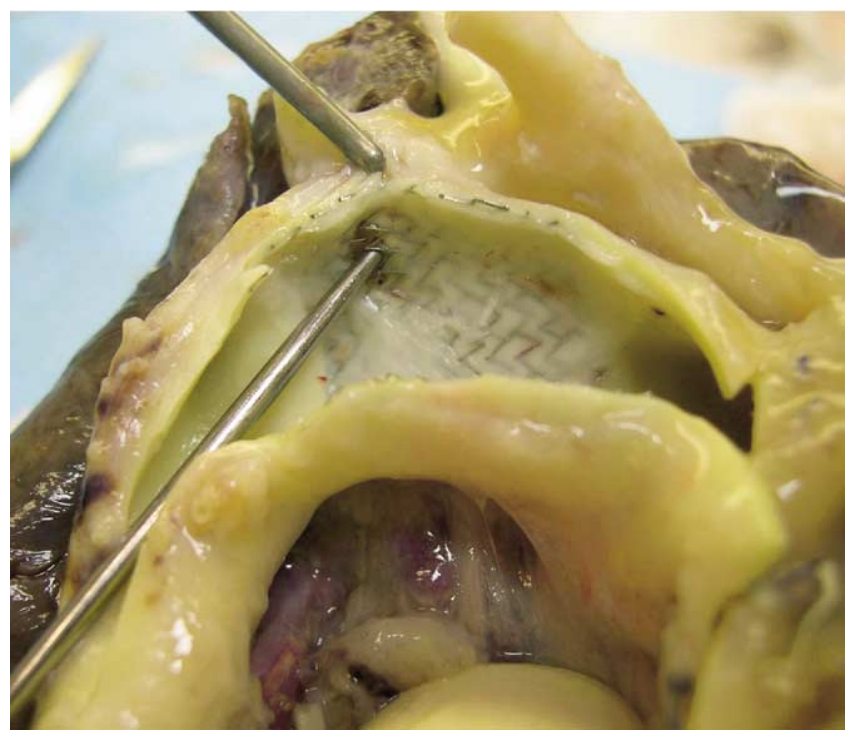

Figure 5. Ductal stent well embedded after 5 months (patient 7). The opening into the transverse arch is shown with a probe.

Banding the branch PA may lead to stenosis or distortion. However, data from Denver in the pretransplantation PA-banded population support the notion that PA bands do not induce prohibitive stenoses. ${ }^{14}$ Furthermore, aortopulmonary shunts and right ventricle/PA conduits also carry the possibility of PA distortion. Since adopting the method of the selective branch PA angiogram (described previously), we have not had to revise bands in the last 10 patients. We also now routinely patch the left PA at the time of the stage II procedure. The right PA has not been a problem because the vessel has opened nicely (Figure E4) after band removal and because the superior vena cava is anastomosed directly over the band site.

A final disadvantage is that a reliable atrial septostomy is difficult to achieve with the hybrid stage I procedure. Our experience with atrial stenting in the long term is mixed at best. As a consequence, we do not rely on atrial stents for more than 3 months. Patients who have atrial stents are scheduled for an elective stage II procedure at 3 to 4 months of age.

\section{Current Indications}

On the basis of our current experience, we believe that the hybrid stage I operation is indicated in neonates with major noncardiac genetic defects, cerebral hemorrhage, intact or highly restrictive atrial septa, poor ventricular function, late presentation, nonresolving end-organ damage from shock at presentation, and nonresolved sepsis (in unstable patients). We believe that this operation is contraindicated in neonates with a possibility of preductal coarctation in aortic atresia or neonates with interruption of the aortic arch (danger of ductal stent embolization). The role of the hybrid stage I procedure remains unclear in patients with aortic atresia without evidence of arch stenoses and in low-risk patients with HLHS or other single-ventricle anomalies, who currently have improved survival.

\section{The Future}

Development of new technologies will undoubtedly improve outcomes and widen the indications of less invasive hybrid strategies. Absorbable stents for temporary ductal stenting, improved intraoperative imaging, or ultrasound tissue erosion $^{28}$ for percutaneous creation of an unrestrictive atrial septal defect, as well as percutaneous flow occluders, could help surmount some of the early problems seen in this study. Oral prostaglandins in conjunction with branch PA banding have also been used. This would theoretically circumvent the problem of retrograde coarctation. Safer techniques for direct cardiac access for delivery of devices through the unopened chest would render the sternotomy obsolete.

\section{Conclusion}

The hybrid stage I palliation is a valid option in high-risk neonates. As experience is accrued, it may become the preferred alternative. However, in aortic atresia, the development of preductal retrograde coarctation is a significant potential problem.

\section{References}

1. Ashburn DA, McCrindle BW, Tchervenkov CI, Jacobs ML, Lofland GK, Bove EL, et al. Outcomes after the Norwood operation in neonates with critical aortic stenosis or aortic valve atresia. $J$ Thorac Cardiovasc Surg. 2003;125:1070-82

2. Sano S, Ishino K, Kado H, Shiokawa Y, Sakamoto K, Yokota M, et al. Outcome of right ventricle-to-pulmonary artery shunt in first-stage palliation of hypoplastic left heart syndrome: a multi-institutional study. Ann Thorac Surg. 2004;78:1951-8.

3. Gaynor JW, Mahle WT, Cohen MI, Ittenbach RF, DeCampli WM, Steven JM, et al. Risk factors for mortality after the Norwood procedure. Eur J Cardiothorac Surg. 2002;22:82-9.

4. Tweddell JS, Hoffman GM, Mussatto KA, Fedderly RT, Berger S, Jaquiss RD, et al. Improved survival of patients undergoing palliation of hypoplastic left heart syndrome: lessons learned from 115 consecutive patients. Circulation. 2002;106:I82-9.

5. Stasik CN, Goldberg CS, Bove EL, Devaney EJ, Ohye RG. Current risk factors for the Norwood procedure: surmounting traditional challenges [abstract]. Presented at the annual meeting of The Western Thoracic Surgical Association, Victoria, BC, Canada, June 22-25, 2005.

6. Goldberg CS, Schwartz EM, Brunberg JA, Mosca RS, Bove EL, Schork MA, et al. Neurodevelopmental outcome of patients following the Fontan operation: a comparison between children with hypoplastic left heart syndrome and other functional single ventricle lesions. J Pediatr. 2000;137:646-52.

7. Galli KK, Zimmerman RA, Jarvik GP, Wernovsky G, Kuypers MK, Clancy RR, et al. Periventricular leukomalacia is common after neonatal cardiac surgery. J Thorac Cardiovasc Surg. 2004;127:692-704.

8. Newburger JW, Wypij D, Bellinger DC, du Plessis AJ, Kuban KC, Rappaport LA, et al. Length of stay after infant heart surgery is related to cognitive outcome at age 8 years. J Pediatr. 2003;143:67-73. 
9. Simisc JM, Bradley SM, Stroud MR, Atz AM. Risk factors for interstage death after the Norwood procedure. Pediatr Cardiol. Published online Nov 5, 2004.

10. Checchia PA, Larsen R, Sehra R, Daher N, Gundry SR, Razzouk AJ, et al. Effect of a selection and postoperative care protocol on survival of infants with hypoplastic left heart syndrome. Ann Thorac Surg. 2004; 77:477-83.

11. Lang P, Norwood WI. Hemodynamic assessment after palliative surgery for hypoplastic left heart syndrome. Circulation. 1983;68:104-8.

12. Ishazaka T, Ohye RG, Suzuki T, Devaney EJ, Bove EL. Bilateral pulmonary artery banding for resuscitation in hypoplastic left heart syndrome. Ann Thorac Surg. 2003;75:277-9.

13. Pizarro C, Norwood WI. Pulmonary artery banding before Norwood procedure. Ann Thorac Surg. 2003;75:1008-10.

14. Mitchell MB, Campbell DN, Boucek MM, Sondheimer HM, Chan $\mathrm{KC}$, Ivy DD, et al. Mechanical limitation of pulmonary blood flow facilitates heart transplantation in older infants with hypoplastic left heart syndrome. Eur J Cardiothorac Surg. 2003;23:735-42.

15. Gibbs JL, Wren C, Watterson KG, Hunter S, Hamilton JR. Stenting of the arterial duct combined with banding of the pulmonary arteries and atrial septectomy or septostomy: a new approach to palliation for the hypoplastic left heart syndrome. Br Heart J. 1993;69:551-5.

16. Akintuerk H, Michel-Behnke I, Valeske K, Mueller M, Thul J, Bauer $\mathrm{J}$, et al. Stenting of the arterial duct and banding of the pulmonary arteries. Basis for combined Norwood stage 1 and 2 repair in hypoplastic left heart. Circulation. 2002;105:1099-103.

17. Galantowicz M, Cheatham JP. Lessons learned from the development of a new hybrid strategy for the management of hypoplastic left heart syndrome. Pediatr Cardiol. 2005;26:190-9.

18. Galantowicz M, Cheatham JP. Fontan completion without surgery. Semin Thorac Cardiovasc Surg Pediatr Card Surg Annu. 2004;7:48-55.

19. Vlahos AP, Lock JE, McElhinney DB, van der Velde ME. Hypoplastic left heart syndrome with intact or highly restrictive atrial septum: outcome after neonatal transcatheter atrial septostomy. Circulation. 2004; 109:2326-30.

20. Lim DS, Peeler BB, Matherne GP, Kron IL, Gutgesell HP. Riskstratified approach to hybrid transcatheter-surgical palliation of hypoplastic left heart syndrome. Pediatr Cardiol. In press.

21. Tanoue Y, Sese A, Ueno Y, Joh K, Hijii T. Bidirectional Glenn procedure improves the mechanical efficiency of a total cavopulmonary connection in high-risk Fontan candidates. Circulation. 2001; 103:2176-80.

22. Berman NB, Kimball TR. Systemic ventricular size and performance before and after bidirectional cavopulmonary anastomosis. $J$ Pediatr. 1993;122:S63-7.

23. Hasegawa T, Yamaguchi M, Yoshimura N, Okita Y. The dependence of myocardial damage on age and ischemic time in pediatric cardiac surgery. J Thor Cardiovasc Surg. 2005;129:192-8.

24. Karimi M, Wang LX, Hammel JM, Mascio CE, Abdulhamid M, Barner EW, et al. Neonatal vulnerability to ischemia and reperfusion: cardioplegic arrest causes greater myocardial apoptosis in neonatal lambs than in mature lambs. J Thorac Cardiovasc Surg. 2004;127: 490-7.

25. Licht DJ, Wang J, Silvestre DW, Nicolson SC, Montenegro LM, Wernovsky G, et al. Preoperative cerebral blood flow is diminished in neonates with severe congenital heart defects. J Thorac Cardiovasc Surg. 2004;128:841-9.

26. Machii M, Becker AE. Nature of coarctation in hypoplastic left heart syndrome. Ann Thorac Surg. 1995;59:1491-4.

27. Aiello VD, Ho SY, Anderson RH, Thiene G. Morphologic features of the hypoplastic left heart syndrome-a reappraisal. Pediatr Pathol. 1990;10:931-43.

28. Xu Z, Ludomirsky A, Eun LY, Hall TL, Tran BC, Fowlkes JB, et al. Controlled ultrasound tissue erosion. IEEE Trans Ultrason Ferroelectr Freq Control. 2004;51:726-36.

\section{Discussion}

Dr Tom R. Karl (San Francisco, Calif). A hybrid is an organism that is an offspring of genetically dissimilar parents said to possess different desirable characteristics, with the premise that the off- spring will possess all of them or, to put it another way, where elements comprising a word are derived from different languages. I think this is a very apt description of this experience.

The credibility of your work is enhanced by the quality of both the surgery and interventional cardiology in your unit, which I think gives you a good advantage for exploring this strategy. The approach has generated results that are very competitive with surgical strategies applied in other units, and moreover the patients have been selected from the most unfavorable end of the hypoplastic left heart spectrum. As such, this approach is certainly deserving of further investigation, especially to test its reproducibility in other centers, since, as you said, currently there are only a handful who have reported results for this strategy, either as a palliation prior to transplant or as a bridge to more definitive stage II construction.

So I have just a few questions.

The first is, how have you modified your Norwood procedure to accommodate the presence of this large stent, which has become very well embedded in the ductus and part of the descending aorta, prior to your intervention?

Dr Bacha. It's a new operation and not so much a modification of the Norwood procedure. It's a big operation. The ductus is rock hard, and removing the ductal stent is not straightforward. I usually don't use circulatory arrest for the Norwood procedure, but you end up having to use circulatory arrest often in this procedure, so there is definitely a trade-off that occurs with a very large stage II operation but a less invasive stage I.

Dr Karl. And did you experience any of the commonly seen extracardiac complications from the Norwood operation when you used this hybrid approach, for example, laryngeal dysfunction, gastrointestinal complications, and so forth?

Dr Bacha. Yes. As I mentioned yesterday, we found the same incidence of laryngeal dysphasia as we saw after the Norwood operation in these patients, prompting us to think that this may be due to more of a genetic makeup of these patients as opposed to surgery causing laryngeal dysfunction.

Dr Karl. The third question is, was any specific anticoagulation regimen employed?

Dr Bacha. We give heparin $50 \mathrm{U} / \mathrm{kg}$ during the procedure after banding, at the time when we are passing the wire into the descending aorta, and those patients are placed on a half a baby aspirin postoperatively.

Dr Karl. Regarding pulmonary artery growth and development with this strategy, has this had an effect on the clinical course following the bidirectional cavopulmonary shunt?

A big concern is that you're subjecting patients to a bidirectional cavopulmonary shunt under difficult circumstances following a long operation, and one would have to have a very good pulmonary bed to achieve success with this second stage. Has this been the case, or have you experienced problems in oxygenation?

Dr Bacha. Well, a lot of the stage II's were done in young patients, closer to 3 months than 6 months. As we know from the Milwaukee series, they will come out of the operating room quite cyanotic and recover over the next days. So generally speaking, I would say the patients have been bluer than I'm used to after the standard cavopulmonary shunt. The left pulmonary artery I find has to be patched at the time of stage II operation, whereas the right pulmonary artery does not have to be patched and you can 
implant the superior vena cava right over the area of the band. However, the key difference is that you now have a circulation in series as opposed to in parallel, as after a Norwood operation.

Dr Karl. And the final question is, do you have a feel for how the results of this strategy compared to results of the standard Norwood operation for similar patients in your own unit? In other words, have you actually improved your results by employing this strategy?

Dr Bacha. Well, it's tough to compare, because since starting this strategy we have not done Norwoods on high-risk patients, so our results have improved somewhat. So overall you would say the Norwood procedure results have improved from my unit because we've excluded now-high-risk patients.

Dr Glen S. Van Arsdell (Toronto, Ontario, Canada). My partner, Chris Caldarone, has embarked on this strategy. We have analyzed $\mathrm{VO}_{2}$ data and have found that the pulmonary blood flow is actually higher and the Qp:Qs is higher than in Norwood patients.

This fact might lead one to assume that there may be some interval problems that are the same as the Norwood's because of the high demands on the myocardium. Has all your interval mortality been explainable by some anatomic problem? Or, as in the Norwood patients, have you sometimes seen mortality that you couldn't explain by an anatomic deficiency?

Dr Bacha. Well, we've had 2 interstage deaths. One was clearly a technical problem with the atrial stent that had migrated. That was autopsy proven. The other was a little bit unclear, and we speculate it's a problem of coronary flow down in the coronaries with a retrograde coarctation in aortic atresia. Most of the deaths, I would say, in this series have been more a learning curve issue and problems with technical aspects of the procedure we have not mastered quite yet.

Dr Christian Pizarro (Wilmington, Del). Emile, I really enjoyed your presentation. I have one question about the self-expanding stent.

I saw that you had migration of the stent in a couple of cases. Perhaps the fact that it is self-expanding, it is an issue in the sense that it's not as well embedded or secured in place immediately after deployment. In our experience we have used balloon-expandable stents, and we had no migration problems. In our practice, the self-expanding stent has always raised discussion about the possibility of migration, and you've clearly shown that that's a valid concern. Based on this, are you changing your practice, or what are your thoughts about this?

Dr Bacha. We've used only self-expandable stents. I don't have any experience with balloon-expandable stents. What we've changed, following the incidence of ductal stent embolization, is that we are oversizing the stent by $1 \mathrm{~mm}$. So if we measure a 7-mm ductus, we'll go to an 8-mm stent. However, migration has been an issue with the self-expandable stents with at least 2 patients in our series.

Dr Frank L. Hanley (Stanford, Calif). I enjoyed the presentation very much.

Given your patient profile, it's not unrealistic that these patients are going to stay in the hospital 7, 8, or 9 weeks given their syndromes, size, and other risk factors. If you put the patients on prostaglandin E and band them, an idea put forth in the Japanese literature, you would reduce the complexity of both your first-stage and your second-stage procedures quite substantially, and since they're going to be in the hospital for a long time anyway, the end result would most likely be very little extra time in hospital between stages I and II, when all is said and done. What do you think about that approach?

Dr Bacha. I think that's a reasonable approach, although I would not favor it necessarily, because obviously with prostaglandin E you have to keep a line in. I guess you could do a peripherally inserted central catheter line and so forth.

The goal here is to get the patient out of the hospital if possible without any lines. Some of the complications that we've seen with ductus stenting, I believe, are more growing pains than problems. I mean, those are problems that we will be able to overcome, I'm pretty sure. 


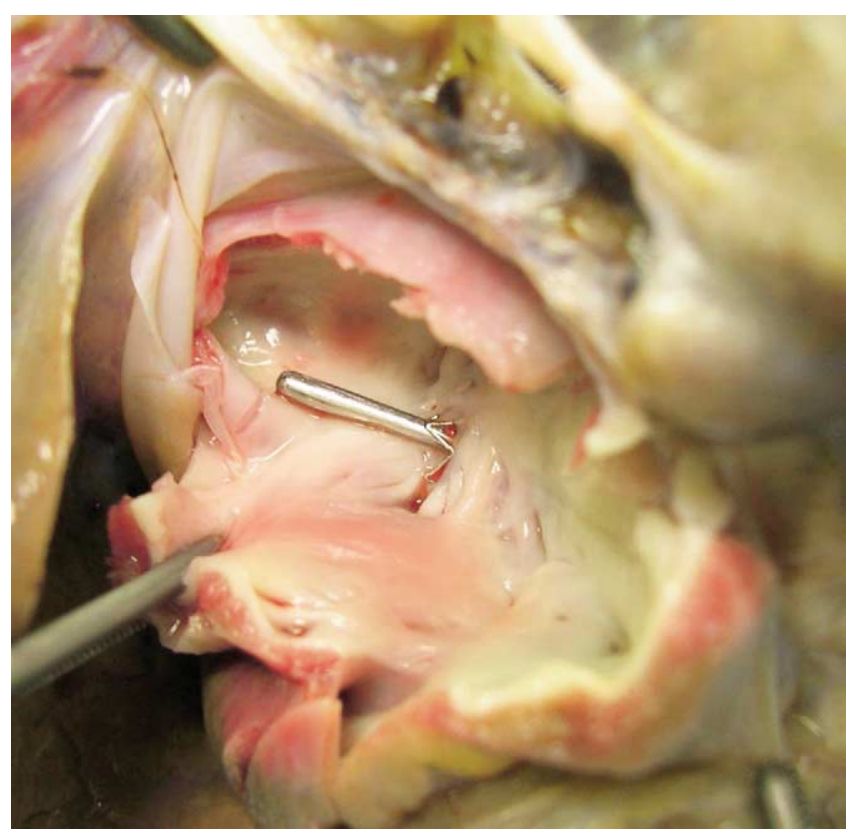

Figure E1. This patient (patient 4) died before the stage II procedure, at 5 months of age, from occlusion of his atrial septum. This photograph shows the left atrial side with a probe through the opening.

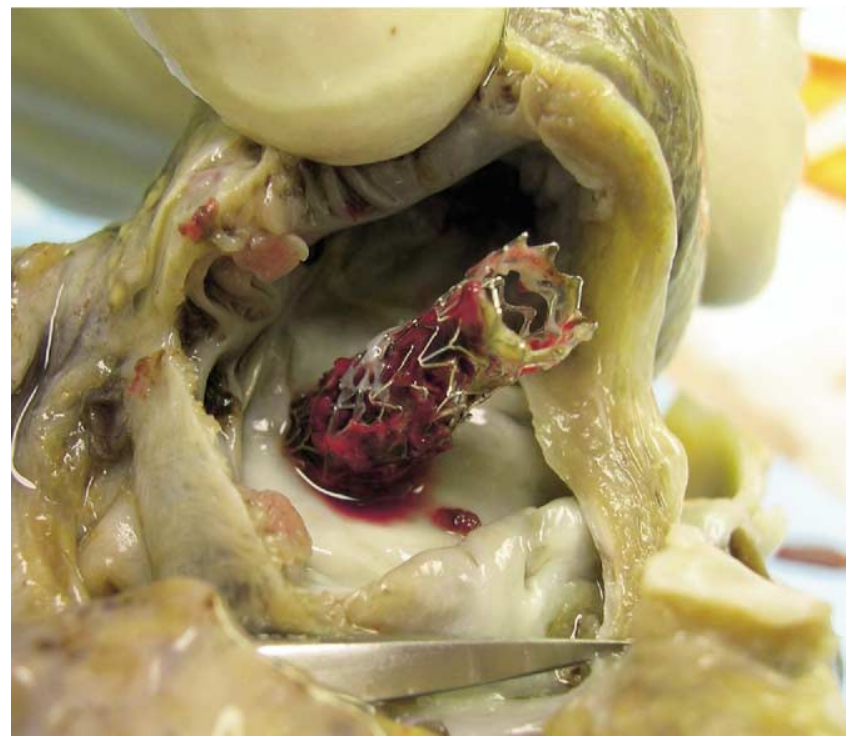

Figure E2. The right atrial side with stent is now almost completely dislodged into the right atrium (patient 4). 


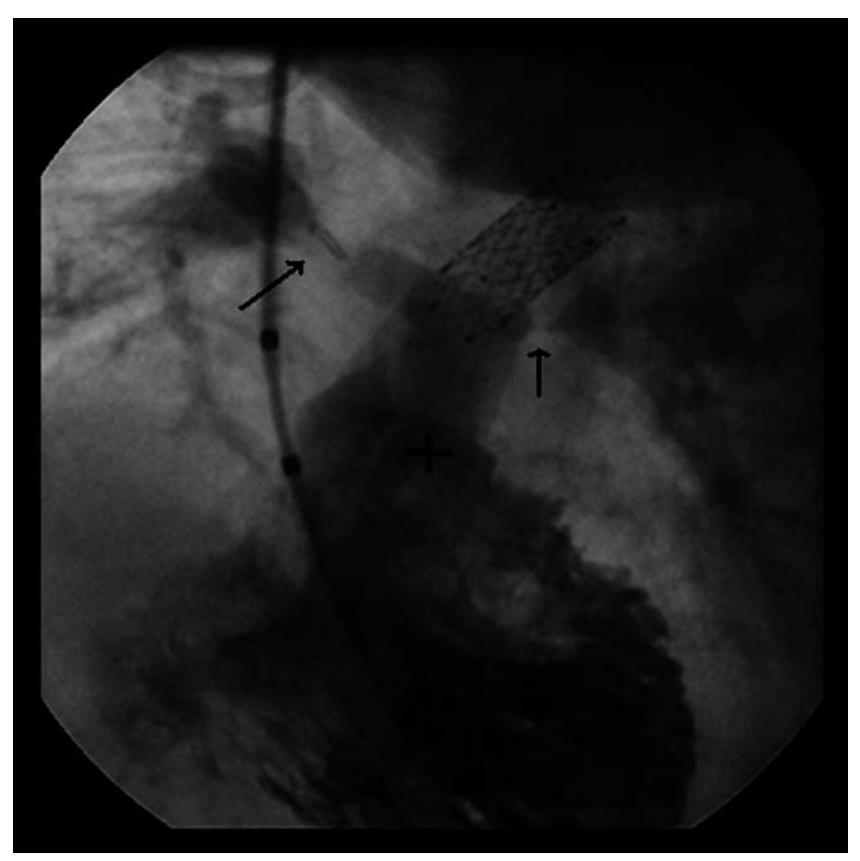

Figure E3. Pre-stage II angiogram showing the banded branch pulmonary arteries (patient 7).
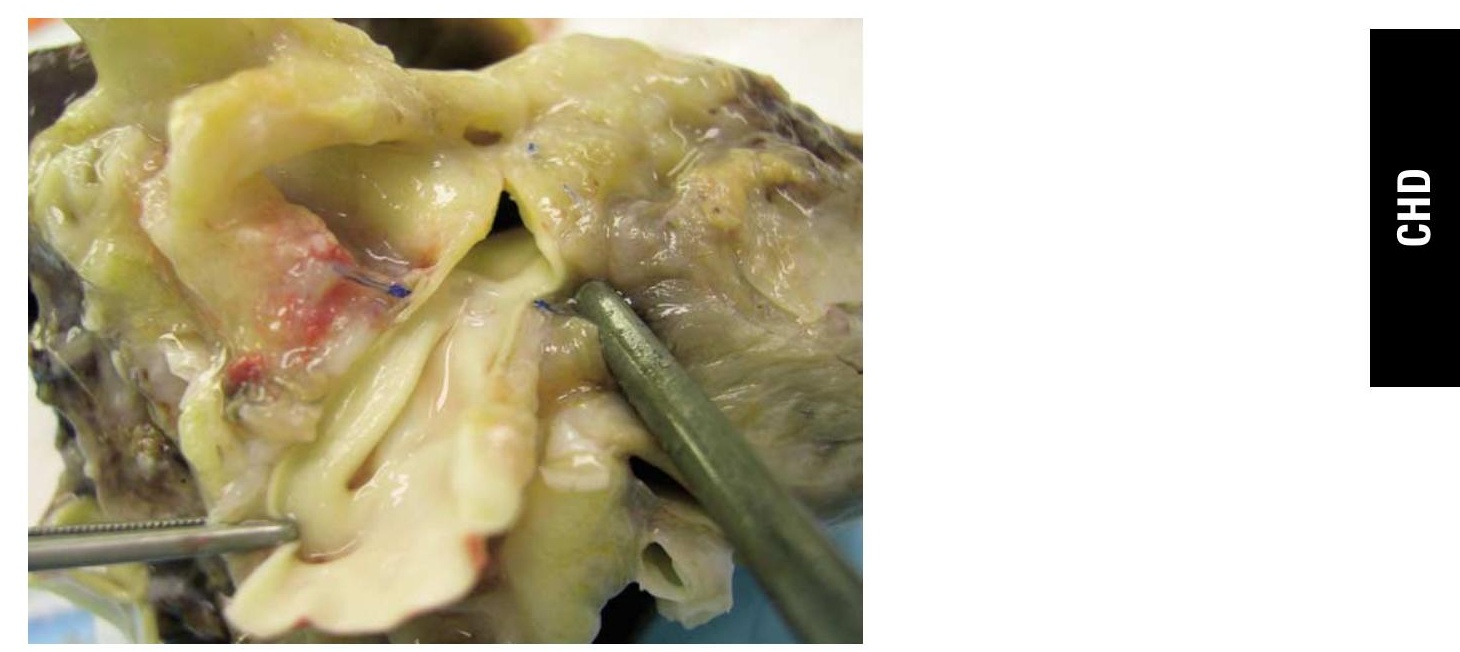

Figure E4. The right PA is opened after 5 months of banding (patient 4). No intimal lesions are seen. 